\title{
Mild Encephalitis with Reversible Splenial Lesion Associated with COVID-19
}

\section{COVID-19 İlişkili Reversibl Splenial Lezyonlu Hafif Ensefalit}

\author{
(1) Esra Demir ${ }^{1}$, (1) Berna Arlin 2 \\ ${ }^{1}$ Ankara Yildirim Beyazit Univeristy Faculty of Medicine, Department of Neurology, Ankara, Turkey \\ 2Ankara City Hospital, Clinic of Neurology, Ankara, Turkey
}

\begin{abstract}
Coronavirus disease-2019 (COVID-19) is an emerging pandemic disease with high morbidity and mortality. The area primarily affected in COVID-19 is the pulmonary system, where the most destructive effect occurs. Symptoms range from asymptomatic illness to mild-to-moderate (mild pneumonia), severe (dyspnea, hypoxia), and critical illness symptoms (acute respiratory distress syndrome, respiratory failure, shock, or multiorgan system dysfunction) in patients with COVID-19. Neurological manifestations, such as acute ischemic stroke, intracerebral hemorrhage, cerebral venous sinus thrombosis, conscious disturbance, febrile seizures, convulsions, mental status change, and encephalitis are observed in severe patients. Mild encephalitis/encephalopathy with reversible splenial (MERS) lesions is a clinicoradiological diagnosis that is associated with a prominent reversible lesion in the corpus callosum (SCC) splenium, infectious agent, and mild encephalopathy. In this case report, the key clinical and radiological features of MERS were highlighted in an adult patient presented to the emergency department with nausea, vomiting, and unconsciousness and admitted to the neurology clinic due to diffusion restriction in the SCC splenium.
\end{abstract}

Keywords: Coronavirus, encephalitis, encephalopathy, reversible corpus callosum splenium lesion

\section{$\ddot{O} \mathbf{z}$}

Koronavirüs hastalı̆̆ı-2019 (COVID-19), yüksek morbidite ve mortalite ile ortaya çıkan pandemik bir hastalıktır. COVID-19'da öncelikle etkilenen alan pulmoner sistem olup en yıkıcı etki de burada ortaya çıkar. Enfekte hastalarda asemptomatik hastalıktan hafif ve orta dereceli semptomlara (hafif pnömoni), şiddetli semptomlara (dispne, hipoksi) ve kritik hastalık semptomlarına (akut solunum sıkıntısı sendromu, solunum yetmezliği, şok veya multiorgan sistem disfonksiyonu) kadar çeşitli semptomlarla ortaya çıkar. Nörolojik belirtilerde, özellikle şiddetli hastalarda, akut iskemik inme, intraserebral kanama, serebral venöz sinüs trombozu, bilinç bozukluğu, ateşli nöbetler, konvülsiyonlar, mental durum değişikliği ve ensefalit görülebilir. Reversibl splenial lezyonlu hafif ensefalit/ ensefalopati (MERS) klinik ve radyolojik bir tanı olup korpus kallosum spleniumda reversibl belirgin bir lezyon, enfeksiyöz bir ajan ve hafif ensefalopati ile ilişkilidir. Bu olgu sunumunda, acil servise bulantı kusma ve bilinç bozukluğu ile başvuran korpus kallozum spleniumda difüzyon kısıtlaması nedeniyle nöroloji kliniğine kabul edilen erişkin bir hastada MERS'nin ana klinik ve radyolojik özelliklerini vurguladık.

Anahtar Kelimeler: Koronavirüs, ensefalit, ensefalopati, geçici korpus kallozum splenium lezyonu

\section{Introduction}

With the continuous spread of the Coronavirus disease-2019 (COVID-19) pandemic, different neurological symptoms and signs continued to be reported. Mild encephalitis/encephalopathy with reversible splenium (MERS) is a clinicoradiographical condition characterized by a reversible lesion isolated to the corpus callosum (SCC) on magnetic resonance imaging (MRI). In this case report, the key clinical and radiological features of MERS in an adult patient were highlighted.

\section{Case Report}

A 50-year-old male patient was admitted to the emergency department with complaints of fever, nausea, vomiting, and impaired consciousness for 3 days. His medical history revealed no illness or drug use. The patient reported a loss of appetite, tiredness, hiccups, and described slow and messy thinking. Before admission, he was independently performing the activities of daily living, actively employed, and cognitively high functioning. A review of systems revealed myalgias, hoarse voice, fatigue, and a mild non-

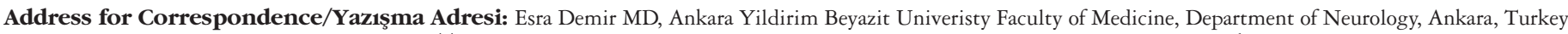
Phone: +90 5445578998 E-mail: md.esrademir@gmail.com ORCID: orcid.org/0000-0002-1752-9619

Received/Geliş Tarihi: 15.06.2020 Accepted/Kabul Tarihi: 08.05.2021

${ }^{\circ}$ Copyright 2021 by Turkish Neurological Society

Turkish Journal of Neurology published by Galenos Publishing House. 
productive cough along with nausea and vomiting for several days. Upon the initial physical examination, he was confused, partially oriented to questions, and partially cooperated with verbal commands. Verbal responses were slowly articulated and sluggish, though not dysarthric. The temperature was $36.8{ }^{\circ} \mathrm{C}$, the blood pressure was $115 / 70 \mathrm{mmHg}$, and the pulse rate was 90 beats $/ \mathrm{min}$. He had bibasilar rales and oxygen saturation of $95 \%$ of the room air. Cranial nerve examination was normal. Motor strength was full in the proximal and distal muscles of the extremities. Light touch sensation on the face, trunk, and extremities was normal. Patellar and ankle reflexes were symmetric. Tandem gait was clumsy, Romberg sign was positive, and finger-to-nose testing was impaired. He had significantly elevated systemic inflammatory markers, including elevated C-reactive protein $(170 \mathrm{mg} / \mathrm{dl}$, reference range $<0.50)$, erythrocyte sedimentation rate $[108(\mathrm{H})$ $\mathrm{mm} / \mathrm{h}$, ref $0-20]$, interleukin-6 $(22.5 \mathrm{pg} / \mathrm{ml}$, ref $<5.00)$, leucocytes $\left[11.2 \times 10^{3} / \mathrm{mm}^{3} \quad(72 \%\right.$ lymphocyte) ref $3.9-10.2)$, platelets (450x103/ $\mathrm{mm}^{3}$, ref $\left.150-400\right)$, fibrinogen $(>1000 \mathrm{mg} / \mathrm{dl}$, ref $173-$ $430)$ and D-dimer $(11.91 \mathrm{mcg} / \mathrm{ml}$, ref $<0.501$, and ferritin $(3780$ $\mathrm{ng} / \mathrm{ml}$, ref 20-200). A toxic, metabolic, and extensive infectious study was conducted, including serological and cerebrospinal fluid (CSF) testing in terms of possible etiological pathologies. He was evaluated for COVID-19, and a chest computed tomography (CT) scan revealed a wide area of consolidation with patchy infiltration and budded tree views accompanying areas of acinar nodular infiltration (Figure 1). His non-contrast brain CT was normal.

Contrast-enhanced brain MRI and diffusion-weighted imaging (DWI) MRI were performed for encephalitis. DWI MRI showed a diffusion-restricted lesion in the SCC splenium, whose counterpart was seen in ADC (Figure 2). It was consistent with the "temporary splenium lesion", alternatively referred to as "cytotoxic lesion of the corpus callosum (CLOCC)". His symptoms were compatible with COVID-19, and neurologic findings were significant for encephalitis. Electroencephalogram (EEG) showed diffuse slowing. Lumbar puncture was performed and his CSF was evaluated in terms of the most common various viral and bacterial infectious agents with CSF cell count, biochemistry, culture, and limbic encephalitis panel. All the tests were evaluated as negative. His nasopharyngeal and oropharyngeal viral test swabs were concluded to be positive for severe acute respiratory syndrome

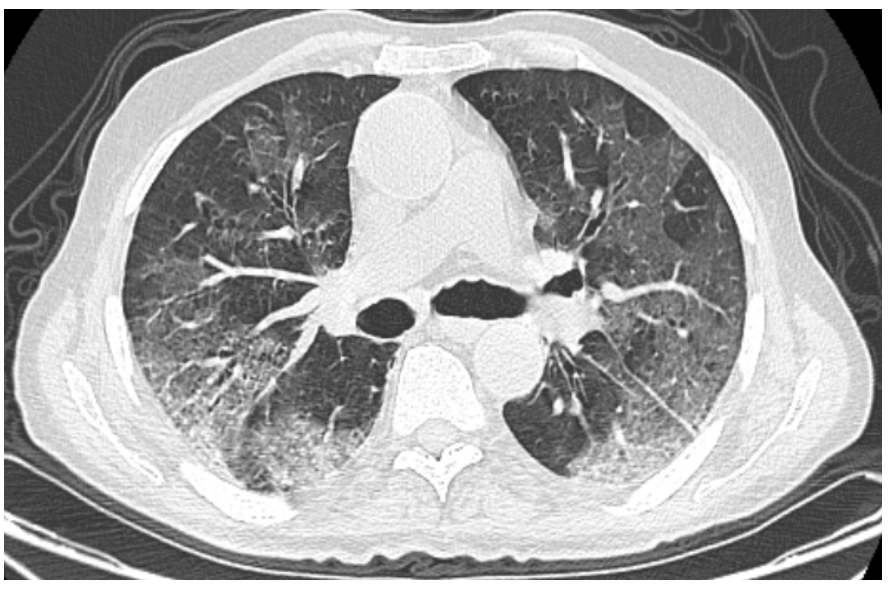

Figure 1. A thoracic computed tomography revealed a wide area of consolidation with patchy infiltration and budded tree views accompanying areas of acinar nodular infiltration coronavirus-2 (SARS CoV-2) in repetitive samples. Therefore, the patient was diagnosed with MERS. The patient was treated with viral-bacterial encephalopathy protocol and ceftriaxone $(4000 \mathrm{mg} /$ day)-acyclovir $(10 \mathrm{mg} / \mathrm{kg}$ per $8 \mathrm{~h}$ ) treatments for 5 days along with low dose cortisone $(0.15 \mathrm{mg} / \mathrm{kg} / \mathrm{day})$. Many literature works recommend only observation without treatment; however, other possible viral and bacterial agents, which can cause mortal results, should be avoided. Favipiravir (1200 mg/day) and azithromycin (250 mg/day) were also started for COVID-19 treatment. Symptom resolution began on day 4; the patient subsequently improved to near his baseline mental status on the fourth day. He was evaluated with diffusion-weighted imaging MRI, and total resolution without diffusion restriction in the splenium was observed (Figure 3). EEG findings were also normal. The patient was discharged with follow-up without any treatment.

\section{Discussion}

MERS is a clinicoradiographical condition characterized by a reversible lesion isolated to the SCC on MRI (1). Patients with MERS typically present with fever, seizure, confusion, and delirium (2). A rare condition that is commonly encountered in viral infections as well as antiepileptic medication withdrawal,

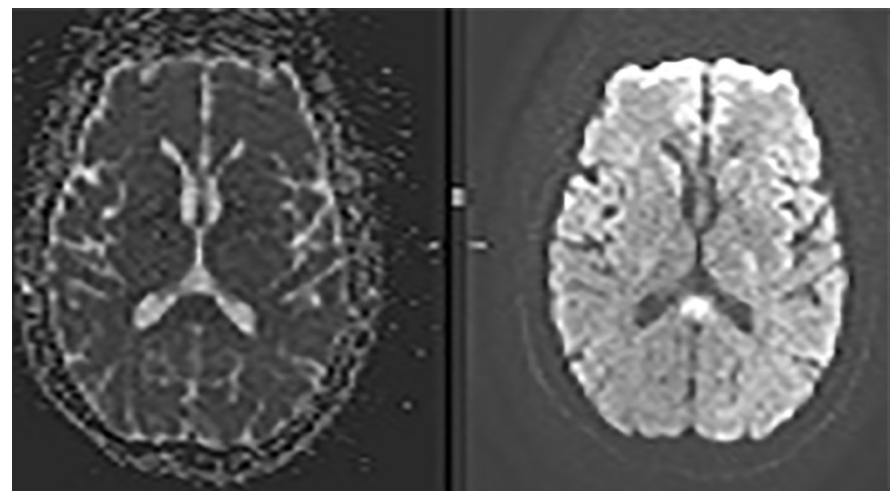

Figure 2. In the corpus callosum splenium section, the appearance is consistent with the "temporary splenium lesion" with diffusion restriction in the center of the corpus callosum splenium in DWI and ADC map in MRI

DWI: Diffusion-weighted imaging, MRI: Magnetic resonance imaging

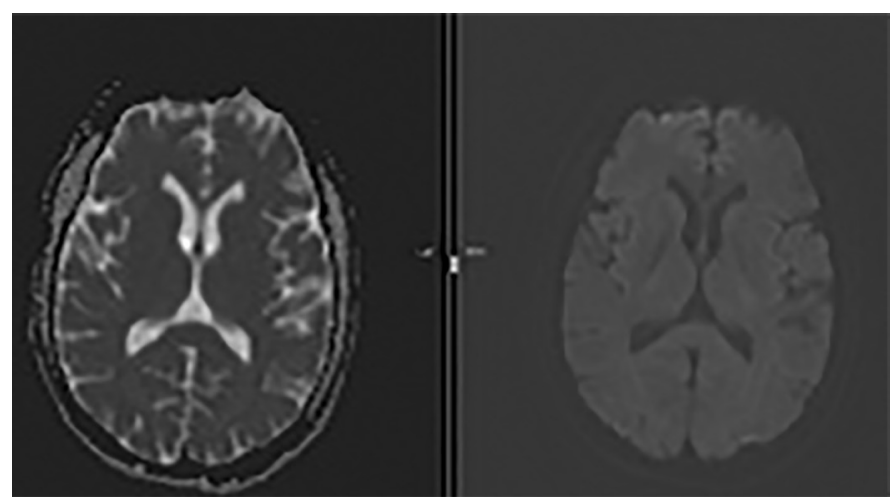

Figure 3. DWI and ADC map do not show diffusion restriction in the patient's control MRI

DWI: Diffusion-weighted imaging, MRI: Magnetic resonance imaging 
high-altitude exposure, and metabolic disturbances (2). Most cases of MERS were mainly reported in children, with approximately 12 adult cases reported in the literature from Japan, Hong Kong, India, and Turkey due to influenza viruses (3). Recently, a few cases of MERS associated with COVID-19 were reported $(4,5)$.

The clinical symptoms of the conditions accompanying the reversible lesion in the SCC are non-specific and diverse, mainly because they reflect a wide spectrum of conditions suggestive of encephalopathy or encephalitis. A fever that precedes or accompanies neurological symptoms is the most common prodromal manifestation. Other general clinical symptoms include headache and digestive tract disturbances (vomiting and diarrhea) $(6,7)$. Our patient experienced fever along with cough, nausea, and vomiting, which were primarily due to the viral cytokine storm. In addition, cognitive impairment, seizures, behavior changes, drowsiness, confusion, acute urinary retention, and delirium are the common neurological symptoms (6). The patient's primary complaint was gastric disturbances, but confusion, decreased environmental interest, and incoordination to daily occupations were experienced a few days later.

A reversible lesion in the SCC is observed upon MRI in a wide range of disorders. Brain MRI identified a restricted diffusion without contrast-enhancing lesions in the SCC (8). Therefore, considering it as a secondary change is better rather than a characteristic finding of mild encephalitis/encephalopathy. Many studies showed that MRI findings disappear after the acute phase. Hayashi et al. (4) reported an adult patient with preceding neurologic comorbidities developing MERS associated with COVID-19. They notified the resolution of neurologic symptoms in 1 week (4). El Aoud et al. (5) described the improvement in neurologic disturbances in 1 week in an adult patient with MERS related to SARS CoV-2 infection and showed the resolution of the splenial lesion at 1-month follow-up MRI without any immunomodulatory therapy. Splenial lesions disappeared in the control diffusion MRI performed 1 week later in our patient (Figure 2). In recent years, the CLOCC was preferred to describe these lesions (9).

In summary, MERS is associated with numerous infectious agents in children and adults and presents with clinically mild encephalopathy characterized by radiographic findings upon brain MRI and resolves without specific treatment. Clinicians should be aware of this disorder and include it in their differential encephalopathy diagnosis, particularly during the COVID-19 pandemic.

\section{Ethics}

Informed Consent: Patient consent was obtained.

Peer-review: Externally and internally peer-reviewed.

\section{Authorship Contributions}

Concept: E.D., B.A., Design: E.D., B.A., Data Collection or Processing: E.D., B.A., Analysis or Interpretation: E.D., B.A., Literature Search: E.D., B.A., Writing: E.D., B.A.

Conflict of Interest: No conflict of interest was declared by the authors.

Financial Disclosure: The authors declared that this study received no financial support.

\section{References}

1. Ka A, Britton P, Troedson C, et al. Mild encephalopathy with reversible splenial lesion: an important differential of encephalitis. Eur J Paediatr Neurol 2015;19:377-382.

2. Garcia-Monco JC, Cortina IE, Ferreira E, et al. Reversible splenial lesion syndrome (RESLES): what's in a name? J Neuroimaging 2011;21:e1-e14.

3. Fluss J, Ferey S, Menache-starobinski C, et al. Mild influenza-associated encephalopathy/ encephalitis with a reversible splenial lesion in a Caucasian child with additional cerebellar features. Eur J Paediatr Neurol 2010;14:97100 .

4. Hayashi M, Sahashi Y, Baba Y, Okura H, Shimohata T. COVID19-associated mild encephalitis/ encephalopathy with a reversible splenial lesion. J Neurol Sci 2020;415:116941.

5. El Aoud S, Sorial D, Selmaoui A, et al. A first case of Mild Encephalitis with Reversible Splenial Lesion (MERS) as a presenting feature of SARS-CoV-2. Rev Neurol (Paris) 2021;177:139-141.

6. Tada H, Takanashi J, Barkovich AJ, et al. Clinically mild encephalitis/ encephalopathy with a reversible splenial lesion. Neurology 2004;63:18541858

7. Takanashi J. Two newly proposed infectious encephalitis/encephalopathy syndromes. Brain Dev 2009;31:521-528.

8. Shankar B, Narayanan R, Muralitharan P, et al. Evaluation of mild encephalitis/ encephalopathy with a reversible splenial lesion (MERS) by diffusion-weighted and diffusion tensor imaging. BMJ Case Rep 2014;2014:bcr2014204078.

9. Starkey J, Kobayashi N, Numaguchi Y, Moritani T. Cytotoxic lesions of the corpus callosum that show restricted diffusion: Mechanisms, causes, and manifestations. Raediographics 2017;37:562-576. 